\title{
GERAKAN PENDIDIKAN AL-WASHLIYAH DI SUMATERA UTARA
}

\author{
Dja'far Siddik \\ Rosnita
}

(Fakultas Ilmu Tarbiyah dan Keguruan IAIN Sumatera Utara

E-mail: isyraqi1984@yahoo.co.id)

Abstract: In the context of Islamic organization in Indonesia, researchers tend to focus their study on the well-known Muslim organizations, such as NU and Muhammadiyab; they tend to overlook other Islamic movements, such as Al-Jam'iyatul Washliyah in Northern Sumatera. This article examines Al-W ashilah's history and role, especially in education that covers its educational institutions, types, and problems. It argues that AlWashliyah is very committed to the dynamics of Islamic education in the country, and plays a role as a stronghold for the Sunni tradition. AlWashilah has contributed to the formation of Islamic culture in Malay world (Nusantara) since the colonial era and is concerned with broader issues, ranging from politics, culture, propagation, economy to education. AlWashliyah has long played an important role for the continuity of the tradition of Islam in Indonesia.

Abstrak: Penellitian tentang organisasi kemasyarakatan di Indonesia penting dilakukan yang hasilnya berkontribusi penting bagi kajian Islam Indonesia. Tulisan ini mengkaji sejarah organisasi Al-Jam'iyatul Washliyah di Sumatera Utara dalam konteks kontribusinya dalam membangun peradaban Islam Nusantara terutama dalam bidang pendidikan. Al-Washliyah telah lama memainkan peranan penting bagi kontinuitas tradisi Islam di Indonesia. Secara lebih spesifik, artikel ini memotret gerakan pendidikan Al-Washliyah yang mencakup sejarah, tipologi, eksistensi, dan problematika lembaga-lembaga pendidikannya. Penulis menemukan bahwa Al-Washliyah memiliki komitmen tinggi terhadap dinamika pendidikan Islam di tanah air, babkan memainkan peran sebagai benteng bagi tradisi Sunni.

Keywords: gerakan pendidikan, Al-Washliyah, Sunni, Sumatera Utara. 
MENURUT Steenbrink, ada empat faktor pendorong terpenting bagi perubahan Islam di Indonesia pada permulaan abad XX. Pertama, munculnya keinginan kembali kepada Alquran dan hadis yang dijadikan sebagai titik tolak untuk menilai kebiasaan agama dan kebudayaan yang ada. Kedua, perlawanan nasional terhadap penguasa Kolonial Belanda. Ketiga, usaha kuat dari orang-orang Islam untuk memperkuat organisasinya dalam bidang sosial ekonomi, baik demi kepentingan umum maupun individu. Keempat, adanya pembaruan dalam bidang pendidikan Islam. Menurutnya, keempat faktor ini ikut mendorong secara kuat perubahan umat Islam Indonesia pada masa penjajahan, meskipun tidak dipungkiri keberadaan faktor lainnya yang turut mendukung perubahan tersebut. ${ }^{1}$

Perubahan tersebut didorong oleh kemunculan tidak saja para pembaharu secara personal, tetapi juga secara kolektif. Menurut Deliar Noer, gerakan pembaruan di Indonesia dilancarkan oleh individu maupun kelompok. Secara individu, muncul tokoh-tokoh pembaharu seperti Thaher Jalaluddin, Muhammad Djamil Djambek, Haji Rasul, Haji Abdullah Ahmad, Ibrahim Musa, dan Zainuddin Labai el-Yunusi. Sedangkan secara kelompok, muncul sejumlah organisasi seperti Nahdlatul Ulama (NU), Muhammadiyah, Persatuan Islam, Sarekat Islam, Jami'at al-Khair, al-Irsyad, Persatuan Tarbiyah Islamiyah, al-Ittihadiyah, dan Al-Jam'iyatul Washliyah. ${ }^{2}$ Para peneliti telah banyak mengkaji peran dan kiprah para tokoh dan organisasi itu dalam memperbaiki kondisi internal umat Islam di Indonesia.

Dibandingkan dengan organisasi NU dan Muhammadiyah, Al-Washliyah belum mendapatkan perhatian serius dari para peneliti, padahal organisasi ini telah ikut memberikan kontribusi bagi peradaban Nusantara. Tetapi, kecenderungan para peneliti ini mengakibatkan peran organisasi lain menjadi sangat dimarjinalkan, padahal organisasi-organisasi selain $\mathrm{NU}$ dan

${ }^{1}$ Lihat uraian Karel A. Steenbrink, Pesantren, Madrasah, Sekolah: Pendidikan Islam dalam Kurun Modern (Jakarta: LP3ES, 1986), 26-8.

2Deliar Noer, Gerakan Modern Islam di Indonesia (Jakarta: LP3ES, 1980), 38-113, 317-9. 
Muhammadiyah ikut memberikan kontribusi bagi bangsa Indonesia.

Artikel ini akan membahas peran Al-Washliyah bagi pendidikan di Sumatera Utara. Secara khusus, akan dilihat sejarah dan pemikiran keagamaan Al-Washliyah, komitmennya bagi dunia pendidikan Islam, tipologi dan keberadaan lembagalembaga pendidikannya.

\section{Al-Washliyah di Sumatera Utara}

Al-Washliyah adalah organisasi Islam yang muncul dari kegiatan ilmiah sejumlah pelajar Sumatera Timur pada era Kolonial. Sejarah organisasi ini diawali tatkala sejumlah perantau Mandailing di Kota Medan mendirikan sebuah lembaga pendidikan Islam bernama Maktab Islamiyah Tapanuli (MIT). MIT berdiri pada tanggal 19 Mei 1918 (09 Sya’ban 1336 H) di Medan. MIT memiliki tenaga pengajar yang merupakan sejumlah ulama terkemuka Sumatera Utara seperti Syekh Dja'far Hasan (w. 1950), Syekh Muhammad Yunus (w. 1950) dan Syekh Yahya. ${ }^{3}$ Guru-guru MIT dikenal sebagai ulama kharismatik dan mumpuni dalam sejumlah bidang keislaman, dan fakta ini menjadi faktor penentu bagi kemajuan lembaga pendidikan ini.

Para guru MIT cukup berhasil mendidik murid-muridnya secara baik, dan pernyataan ini dibuktikan oleh fakta bahwa murid-murid senior lembaga pendidikan ini gemar melakukan diskusi ilmiah. Para pelajar senior lembaga pendidikan tersebut mendirikan Debating Club, sebuah kelompok studi pada tahun 1928 sebagai wadah untuk mendiskusikan pelajaran maupun persoalan sosial-keagamaan. ${ }^{4}$ Perkumpulan ini dipimpin para pelajar senior terbaik MIT yang kelak merupakan para pendiri Al-Washliyah. Para pelajar energik tersebut adalah Abdurrahman

${ }^{3}$ Mahmud Yunus, Sejarah Pendidikan Islam di Indonesia (Jakarta: Hidakarya Agung, 1993), 193; Muaz Tanjung, 'Pendidikan Islam di Medan Pada Awal Abad ke-20: Studi Historis tentang Maktab Islamiyah Tapanuli (19181942)", Tesis (Medan: PPS IAIN-SU, 2004); Ja'far, "Maktab Islamiyah Tapanuli: Sebuah Cermin Berharga Bagi HIMMAH," dalam Potret HIMMAH: Menyibak Sejarah, Gerakan dan Identitas, ed. Ja'far dan Ahmad Mushlih (Banda Aceh: PeNA, 2007).

${ }^{4}$ Hasan Asari, Modernisasi Islam: Tokoh, Gagasan dan Gerakan (Bandung: Citapustaka Media, 2002), 235. 
Syihab, Syamsuddin (Kular), Ismail Banda, Adnan Nur, dan Sulaiman. ${ }^{5}$ Mereka kerap mengadakan diskusi-diskusi ilmiah setiap malam Jumat, minimal sekali dalam seminggu.

Belakangan, para eksponen kelompok diskusi ini merasakan bahwa kegiatan ilmiah selama ini tidak hanya sebatas membahas pelajaran semata, tanpa memberikan kontribusi nyata bagi umat Islam. Dinamika kelompok diskusi ini akhirnya memunculkan keinginan mendirikan sebuah perkumpulan besar dan mampu memberikan kontribusi bagi kehidupan umat Islam. Beberapa pertemuan diadakan untuk membicarakan rencana mulia tersebut.

Pada pertemuan tanggal 26 Oktober 1930 di gedung MIT, yang dihadiri oleh sejumlah pelajar, ulama, dan masyarakat Muslim Kota Medan, mengambil keputusan penting mendirikan sebuah perhimpunan atau organisasi. Syekh Muhammad Yunus diberi amanah memberikan nama untuk organisasi tersebut. Setelah melakukan munajat, akhirnya ia memutuskan untuk memberi nama organisasi ini dengan nama "Al-Jam'iyatul Washliyah," yang artinya adalah perhimpunan yang memperhubungkan dan mempertalikan. ${ }^{6}$ Sebagai langkah awal, ditetapkanlah struktur kepengurusan awal dan tugas pengurus ini adalah mempersiapkan beberapa hal menyangkut masalah keorganisasian seperti rancangan Anggaran Dasar dan Anggaran Rumah Tangga organisasi. Adapun struktur awal kepengurusan itu adalah ketua (Ismail Banda), sekretaris (Muhammad Arsyad Thalib Lubis), bendahara (H. M. Ya'kub), dan anggota (Kular, H. A. Malik, Abdul Azis Effendi, dan Muhammad Nurdin). ${ }^{7}$

Setelah mempersiapkan segala kebutuhan, pengurus awal tersebut mengadakan sebuah pertemuan pada tanggal 9 Rajab 1349/30 November 1930 untuk mendeklarasikan perhimpunan yang bernama Al-Jam'iyatul Washliyah. Para peserta dalam pertemuan tersebut memberikan perhatian besar dan dukungan terhadap rancangan organisasian baru ini. Pertemuan tersebut berhasil meresmikan Al-Jam’iyatul Washliyah sebagai sebuah

${ }^{5}$ Nukman Sulaiman (ed.), Al-Jam'ijatul Washlijab 1/4 Abad (Medan: PB Al Washlijah, 1956), 36.

'Ibid., 38.

${ }^{7}$ Ibid. 
organisasi, dan mengamanahkan organisasi baru ini kepada Ismail Banda (Ketua), Abdurrahman Syihab (Wakil ketua I), Muhammad Arsyad Thalib Lubis (Sekretaris), Adnan Nur (Sekretaris I), H.M.Ya'kub (Bandahara), dan beberapa anggota H. Syamsuddin, H. Yusuf Ahmad Lubis, H. Abdul Malik, dan Abdul Azis Effendi. Sedangkan Syekh Muhammad Yunus bertindak sebagai penasehat. ${ }^{8}$

Al-Washliyah dapat dianggap sebagai organisasi yang berasal dari ulama dan telah melahirkan banyak ulama. Para pendiri organisasi ini, seperti Ismail Banda, Abdurrahman Syihab, dan Muhammad Arsyad Thalib Lubis, adalah ulama-ulama terkemuka di Sumatera Utara. ${ }^{9}$ Mereka bahkan berguru kepada dua ulama terkemuka kota Medan seperti Syekh Hasan Maksum (Mufti Kerajaan Deli) dan Syekh Muhammad Yunus (Direktur Maktab Islamiyah Tapanuli). Syekh Hasan Maksum adalah murid Syekh Ahmad Khatib al-Minangkabawi (Mufti Mazhab Syafi'i di Masjidilharam), sedangkan Syekh Muhammad Yunus adalah murid Syekh Abdul Qadir al-Mandili (ulama mazhab Syafi'iyah dan pengajar di Masjidilharam). ${ }^{10}$ Ulama-ulama AlWashliyah inilah yang memainkan peran sebagai benteng bagi mazhab Sunni (Syafi'iyah dan Asy'ariyah) di Sumatera Utara.

Sebagai sebuah organisasi, Al-Washliyah didirikan dengan suatu tujuan, sebagaimana dirumuskan pada pertemuan para pelajar senior MIT tahun 1930, yaitu "memajukan, mementingkan dan menambah tersiarnya agama Islam." Pada tahun 1934 tujuan ini mengalami sedikit perubahan redaksi yang dinyatakan bahwa tujuan organisasi ini adalah "berusaha menunaikan tuntutan agama Islam."11 Dalam sidang Pengurus Besar Al-Washliyah tanggal 25 Januari 1979, disebutkan bahwa tujuan Al-Washliyah adalah "melaksanakan tuntunan agama

${ }^{8}$ Ibid., 38.

${ }^{9}$ Majelis Ulama Indonesia Sumatera Utara, Ulama-ulama Terkemuka di Sumatera Utara (Medan: MUI Sumatera Utara, tt.).

${ }^{10} \mathrm{Ja}$ 'far, Biografi Intelektual Ulama-ulama Al-Washliyah (Medan: Centre for Al-Washliyah Studies, 2012).

${ }^{11}$ Udin Sjamsuddin, Chutbah Pengurus Besar Memperingati Ulang Tabun Al Djamijatul Washlijah (Medan: PB Al Washlijah, 1955), 4. 
Islam untuk kebahagiaan dunia dan akhirat."12 Anggaran Dasar Al-Washliyah tahun 2003 menyebutkan bahwa Al-Washliyah bertujuan "mengamalkan ajaran Islam untuk kebahagiaan dunia dan akhirat, mewujudkan masyarakat yang beriman, bertakwa, aman, damai, adil, makmur dan diridai Allah Swt. dalam Negara Kesatuan Republik Indonesia yang berdasarkan Pancasila, dan menumbuhkan gairah dan dorongan yang kuat dalam masyarakat Indonesia untuk turut berperan serta secara aktif dalam pembangunan nasional."13 Dalam Anggaran Al-Washliyah tahun 2010 disebutkan bahwa "Al-Washliyah bertujuan menegakkan ajaran Islam untuk terciptanya masyarakat yang beriman, bertakwa, cerdas, amanah, adil, makmur dan diridai Allah Swt."14 Berdasarkan redaksi tujuan tersebut, dapat disimpulkan bahwa Al-Washliyah hendak mengamalkan ajaran Islam dalam berbagai aspek kehidupan, baik beragama, berbangsa maupun bernegara, demi kebahagiaan dunia sekaligus akhirat. Para pendiri dan ulama Al-Washliyah menegaskan bahwa Al-Washliyah diharapkan dapat menjadi sarana umat Islam untuk merealisasikan ajaran Islam.

Literatur-literatur Al-Washliyah menjelaskan bahwa organisasi ini menjadi sarana bagi realisasi ajaran Islam dalam mazhab Syaficiyah dan Asy'ariyah. Anggaran Dasar Al-Washliyah tahun 1956 disebutkan bahwa "Al-Washliyah melaksanakan tuntutan agama Islam, dalam hukum fikih bermazhab Syafi'i, dan dalam iktikad Ahl Sunnah Waljamaah."'15 Sampai dengan Anggaran Dasar Al-Washliyah tahun 1977 memang masih disebutkan bahwa "perkumpulan ini berasaskan Islam, dalam hukum fikih bermazhab Syafi'i dan dalam iktikad Ahli Sunnah

12PB Al-Washliyah, “Anggaran Dasar Al-Jam'iyatul Washliyah,” dalam Buah Hati Umat-Islam dan Keputusan Muktamar Al-Washliyah ke-XV Pekan Baru-Riau, ed. Bahrum Jamil (Medan: Wajah Islam, 1985), 213.

13Pengurus Besar Al-Jam'iyatul Washliyah, Anggaran Dasar dan Anggaran Rumah Tangga Al-Jam'iyatul Washliyah Periode 2003-2008 (Jakarta: PB AlWashliyah, 2003), 4.

14Pengurus Besar Al-Jam'iyatul Washliyah, Anggaran Dasar dan Anggaran Rumah Tangga Al-Jam'iyatul Washliyah Periode 2010-2015 (Jakarta: Pengurus Besar Al-Jam'iyatul Washliyah, 2010), 6.

${ }^{15}$ Sjamsuddin, Chutbah, 4. 
Waljamaah."16 Pada Muktamar Al-Washliyah ke XV tahun 1978 di Pekan Baru, Anggaran Dasar Al-Washliyah mengalami sedikit tambahan bahwa "Al-Washliyah berlandaskan Pancasila dan UUD 1945, sedangkan Al-Washliyah berasaskan Islam, dalam hukum fikih bermadzhab Syafi'i, dan dalam iktikad Abl Sunnah Waljamaah."17 Dalam Anggaran Dasar Al-Washliyah tahun 2003 dan tahun 2010 disebutkan bahwa Al-Washliyah berasaskan Islam dalam iktikad, dalam hukum fikih bermazhab Ahl Sunnah Waljamaah dengan mengutamakan madzhab Syafici."18 Secara khusus, Al-Washliyah menganut dan mengembangkan mazhab Asy'ariyah. ${ }^{19}$ Sampai periode era Reformasi, lembaga-lembaga pendidikan Al-Washliyah masih mengajarkan dan mengembangkan fikih Syafi'iyah dan doktrin teologi Asy'ariyah. Para ulama Al-Washliyah menulis banyak karya fikih dan teologi Asy'ariyah, ${ }^{20}$ dan fakta ini menjadi bukti bahwa Al-Washliyah

16Pengurus Besar Al-Jam'iyatul Washliyah, Al-Jam'iyatul Washliyah (Medan: PB Al-Washliyah, 1977), 3; Nukman Sulaiman, Bermu'tamarlah dengan Baik: Anjuran Dewan Fatwa, Penasihat, dan Pertimbangan p.b. al- j. washliyah (Muktamar Al-Washliyah XVI di Jakarta) 20-24 Pebruari 1986 (Medan: UNIVA, 1986), 2.

17Pengurus Besar Al-Washliyah, "Keputusan-Keputusan Muktamar AlJam'iyatul Washliyah Tanggal 24-27 September 1978/22-24 Syawal 1398 H di Pekan Baru-Riau," dalam, Buab Hati Umat-Islam dan Keputusan Muktamar Al-Washliyah ke-XV Pekan Baru-Riau, ed. Bahrum Jamil (Medan: Wajah Islam, 1985), 23-6.

18Pengurus Besar Al-Jam'iyatul Washliyah, Anggaran Dasar dan Anggaran Rumah Tangga Al-Jam'iyatul Washliyah Periode 2003-2008 Jakarta: PB AlWashliyah, 2003), 4; Pengurus Besar Al-Jam'iyatul Washliyah, Anggaran Dasar dan Anggaran Rumah Tangga Al-Jam'iyatul Washliyah (Jakarta: PB AlWashliyah, 2010).

${ }^{19 R a m l i}$ Abdul Wahid, “Al-Jam'iyatul Washliyah: Studi Tentang Madzhab Akidah dan Fikih," dalam Peran Moderasi Al-Washliyah: Merajut Kebersamaan Zaman Berzaman, ed. Saiful Akhyar Lubis (Medan: UNIVA Press, 2009), 20-3.

${ }^{20}$ Beberapa karya ini seperti karya Nukman Sulaiman, 'Aqidah Islamiyah (Pokok-pokok Kepercayaan dalam Islam) (Medan: Pustaka UNIVA, 1972); Muhammad Arsyad Thalib Lubis, Fatwa: Beberapa Masalah (Medan: Firma Islamiyah, 1982); Muhammad Arsyad Thalib Lubis, Ilmu Fikib (Medan: Firma Islamiyah, 1982); Ramli Abdul Wahid, Fikib Ramadan (Medan: Perdana Publishing, 2012). 
memainkan peran sebagai perisai dan benteng mazhab Sunni di Sumatera Utara.

Al-Washliyah juga telah merumuskan sifat, fungsi dan usahausaha organisasi ini. Disebutkan bahwa Al-Washliyah adalah organisasi yang bersifat independen. Fungsi organisasi ini adalah 1) sebagai wadah menyalurkan aspirasi anggota dan masyarakat untuk menjalankan peran aktifnya dalam berbagai kegiatan kemaslahatan umat; 2) sebagai wadah pembinaan dan pengembangan anggota dalam mewujudkan tujuan organisasi. Sedangkan untuk mencapai tujuan organisasi, menurut Anggaran Dasar tahun 1950, Al-Washliyah melakukan usaha-usaha 1) memperkuat perhubungan persaudaraan di antara kaum muslimin dan berbuat baik serta berlaku adil terhadap orangorang yang tidak beragama Islam jang memusuhi kaum Muslimin dalam agama dan negerinya; 2) memperbanyak tablig, tazkir, dan pengajian di tengah-tengah kaum muslimin; 3) menyampaikan seruan Islam kepada orang yang belum beragama Islam; 4) mendirikan rumah-rumah perguruan dan mengatur kesempurnaan pelajaran dan pendidikan; 5) menerbitkan kitabkitab, surat kabar, majalah, surat siaran, mengadakan taman bacaan dan gedung kitab; 6) mengadakan pertemuan-pertemuan yang mencerdaskan pikiran dan memperdalam pengetahuan; 7) mendirikan, memperbaiki dan memelihara tempat ibadah; 8) menyantuni dan memelihara fakir miskin dan anak yatim; 9) memajukan dan menggembirakan penghidupan dengan jalan yang halal; 10) mempersiapkan kaum muslimin dalam menegakkan dan mempertahankan kebenaran dan keadilan; 11) mengusahakan berlakunya hukum Islam; 12) dan lain-lain yang ditimbang perlu menurut putusan musyawarah. ${ }^{21}$

Pada saat ini, Al-Washliyah telah memasuki usia ke 82 tahun. Selama ini, organisasi ini telah dipimpin oleh para kader terbaiknya. Di Sumatera Utara, kepengurusan Al-Washliyah sudah mengalami beberapa kali pergantian sejak Pengurus Besar organisasi ini pindah ke Jakarta pada tahun 1986. Pimpinan

21Pengurus Besar Al-Washliyah, "Anggaran Dasar dan Anggaran Rumah Tangga Al Djamiatul Washlijah," dalam Al-Jam'iyatul Washlijah 1/4 Abad, ed. Nukman Sulaiman (Medan: PB Al-Washliyah, 1955), 342; PB AlWashliyah, Anggaran..., 7-8. 
Wilayah Al-Washliyah Sumatera Utara selama ini adalah Drs. H. Usman Serawi (Ketua) dan Ahmad Ikhyar Hasibuan (Sekretaris) untuk periode 1992-1997; H. Abdul Halim Harahap (Ketua) dan H. Dariansyah Emde (Sekretaris) untuk periode 1998-2003; H. Abdul Halim Harahap dan Rijal Sirait (Sekretaris) untuk periode 2003-2005; H. Muhammad Nizar Syarif (Plt. Ketua) dan Rijal Sirait (Sekretaris) periode 2006-2010; dan H. Hasbullah Hadi (Ketua) dan. Yulizar Parlagutan (Sekretaris) periode 2011-2015. Di bawah kepemimpinan mereka, Al-Washliyah telah memberikan sejumlah kontribusi baik dalam bidang pendidikan, dakwah maupun amal sosial.

Sejak berdiri, Al-Washliyah memang memiliki perhatian intens terhadap dunia pendidikan. Sebagai salah satu organisasi pembaharu, Al-Washliyah memainkan peranan tidak kecil bagi perubahan kondisi umat Islam Indonesia. Sejarah membuktikan bahwa Al-Washliyah memberikan perhatian cukup besar terhadap 3 (tiga) bidang yaitu pendidikan, dakwah dan sosial. ${ }^{22}$ Referensi-referensi dalam bidang Sejarah Pendidikan Islam dan Filsafat Pendidikan Islam sedikit banyak telah menjelaskan peran dan kontribusi Al-Washliyah dalam dunia pendidikan Islam di Indonesia. Tetapi, penjelasan beragam referensi tersebut sangat mendalam bahkan tidak berhasil memotret gerakan pendidikan Al-Washliyah secara benar. Karena itu, deskripsi dan analisa terhadap gerakan pendidikan Al-Washliyah menjadi sangat penting, minimal sebagai bentuk nyata dari usaha mengapresiasi peran organisasi ini dalam bidang pendidikan.

\section{Komitmen terhadap Pendidikan}

Sejak berdiri, Al-Washliyah memiliki perhatian besar terhadap dunia pendidikan. Sebagai salah satu organisasi pembaharu, Al-Washliyah memainkan peranan tidak kecil bagi perubahan kondisi umat Islam Indonesia. Steenbrink menyebut organisasi ini sebagai organisasi terbesar ketiga setelah NU dan

${ }^{22}$ Muhammad Ridwan Ibrahim Lubis, Kepribadian Anggota \& Pengurus Al-W ashliyah (Jakarta: PP HIMMAH, 1994), 12. 
Muhammadiyah, ${ }^{23}$ dan merupakan organisasi pembaharu pendidikan Islam di Indonesia. ${ }^{24}$

Sebagai organisasi pembaharu pendidikan Islam, AlWashliyah memiliki komitmen tinggi terhadap pengembangan kualitas pendidikan Indonesia. Dalam Anggaran Dasar dan Anggaran Rumah Tangga Al-Jam'iyatul Washliyah disebutkan bahwa salah satu usaha Al-Washliyah dalam mencapai tujuannya-yaitu menegakkan ajaran Islam untuk terciptanya masyarakat yang beriman, bertakwa, cerdas, amanah, adil, makmur dan diridai Allah Swt.-adalah dengan cara mendirikan lembaga-lembaga pendidikan dalam semua jenis dan jenjang pendidikan, serta mengatur kesempurnaan pendidikan dan pengajaran dan kebudayaan. Usaha lain organisasi ini adalah "melaksanakan amar ma'ruf nahi mungkar dengan cara memperbanyak tabligh, tazkir, ta'lim, penerangan dan penyuluhan di tengah-tengah umat."25 Dalam Wijhah Al-Washliyah disebutkan bahwa "AlWashliyah menilai bahwa pendidikan dan pengajaran, adalah unsur mutlak bagi tegak dan teguhnya Islam, merupakan hal yang wajib bagi pria dan wanita."26 Dalam buku Kepribadian Anggota dan Pengurus Al-W ashliyah disebutkan bahwa "siapa yang memegang pendidikan masa kini, dialah pemimpin hari esok." 27 Disebutkan pula bahwa profesi utama Al-Washliyah adalah "membina intern umat Islam dalam bidang pendidikan, dakwah dan sosial."28 Secara normatif, Al-Washliyah memiliki semangat tinggi untuk mengembangan dunia pendidikan.

Dalam menyelenggarakan pendidikan, Al-Washliyah telah membentuk sebuah majelis yang mengurusi masalah pendidikan. Pada tahun 1934, majelis ini bernama Madjelis Tarbijah. Pada

${ }^{23}$ Karel A. Steenbrink, "Kata Pengantar," dalam Chalidjah Hasanuddin, Al-Jam'iyatul Washliyah 1930-1945: Api Dalam Sekam di Sumatera Timur (Bandung: Pustaka, 1988), vii.

${ }^{24}$ Steenbrink, Pesantren..., 77.

25Pengurus Besar Al-Jam'iyatul Washliyah, Anggaran Dasar dan Anggaran Rumah Tangga Al-Jam'iyatul W ashliyah Periode 2010-2015 Jakarta: Pengurus Besar Al-Jam'iyatul Washliyah, 2010), 6-7.

${ }^{26}$ Ismed Batubara dan Ja'far (ed.), Bunga Rampai Al-Jam'iyatul Washliyah (Banda Aceh: Al-Washliyah University Press, 2010).

${ }^{27}$ Lubis, Kepribadian..., 12.

${ }^{28}$ Ibid., 12-4. 
tahun 1955, majelis ini sudah berganti nama menjadi Majelis Pendidikan, Pengajaran dan Kebudayaan (MPPK). Anggaran Dasar Al-Washliyah tahun 1950 menyebutkan bahwa tugas MPPK adalah "memimpin dan mengatur kesempurnaan perjalanan perguruan, pengadjaran dan pendidikan, memenuhi anggaran dasar pasal 4 bagian d. yaitu mendirikan rumah-rumah perguruan dan mengatur kesempurnaan peladjaran dan pendidikan."29 Dalam sidang Pengurus Besar Al-Washliyah tanggal 25 Januari 1979, disebutkan bahwa tugas Majelis Pendidikan, Pengajaran dan Kebudayaan Al-Washliyah adalah 1) memimpin dan mengatur kesempurnaan jalannya perguruan, pendidikan pengajaran, dan kebudayaan di dalam segala jenis tingkatan madrasah/perguruan serta pendidikan dasar, lanjutan dan perguruan tinggi; 2) mendirikan madrasah-madrasah, pesantren dan perguruan-perguruan yang bersifat agama dan umum; 3) menyiapkan dan menyediakan guru-guru, ulamaulama dan sarjana-sarjana; 4) nengadakan dan mengusahakan beasiswa. ${ }^{30}$

Secara tegas, komitmen Al-Washliyah dalam dunia pendidikan dapat dilihat dari hasil Muktamar Al-Washliyah XIV di Medan. Dalam Muktamar tersebut, Majelis Pendidikan, Pengajaran dan Kebudayaan telah membuat rencana pembangunan Al-Washliyah dalam bidang pendidikan, dan rencana tersebut dibagi menjadi tiga, yakni pendidikan rumah tangga (informal), madrasah/perguruan (formal), dan masyarakat (non-formal). Al-Washliyah memandang bahwa ketiga lingkungan pendidikan tersebut sangat penting digarap dan dibangun. Apabila salah satu lingkungan pendidikan tersebut lemah, maka akan menimbulkan pengaruh dan akibat buruk bagi lingkungan pendidikan lainnya. Muktamar ini bahkan telah merumuskan secara baik tentang tujuan pendidikan ketiga institusi pendidikan ini. Disebutkan bahwa tujuan pendidikan informal Al-Washliyah adalah "membentuk rumah tangga bahagia, harmonis dan penuh diliputi rasa tanggungjawab timbal

${ }^{29}$ Pengurus Besar Al-Washliyah, "Anggaran Dasar dan Anggaran Rumah Tangga Al Djamiatul Washlijah," dalam Al-Jam'iyatul Washlijah 1/4 Abad, ed. Nukman Sulaiman (Medan: PB Al-Washliyah, 1955), 342, 345.

${ }^{30} \mathrm{~PB}$ Al-Washliyah, Keputusan..., 220. 
balik dan rasa ketaqwaan kepada Allah Swt." Tujuan pendidikan madrasah adalah "membentuk manusia mukmin yang taqwa, berpengetahuan luas dan dalam, cerdas dan tangkas dalam berjuang menuntut kebahagiaan dunia dan akhirat." Sedangkan tujuan pendidikan masyarakat adalah "membina masyarakat umat yang beriman dan bertaqwa kepada Allah Swt., memiliki rasa sosial dan perikemanusiaan yang mendalam, serta terikat ketat dengan tali ukhuwah Islamiyah, sesuai dengan ajaran agama Islam dan Pancasila." 31

Sedangkan tujuan pendidikan Al-Washliyah menurut Sistem Pendidikan Al-Washliyah tahun 2000 adalah 1) membentuk manusia mukmin yang bertaqwa, berpengetahuan luas dan dalam, berbudi pekerti yang tinggi, cerdas dan tangkas dalam berjuang menuntut kebahagiaan dunia dan akhirat. 2) mengembangkan dan menyebarkan ilmu pengetahuan, teknologi dan/atau kesenian serta mengupayakan penggunaannya untuk meningkatkan taraf hidup dan menumbuhkembangkan masyarakat madani. ${ }^{32}$ Tujuan pendidikan Al-Washliyah seperti ini pernah diungkap oleh Prof. Nukman Sulaiman, salah seorang ulama Al-Washliyah, pada tahun 1967, dengan menyatakan bahwa tujuan pendidikan Al-Washliyah adalah "membentuk manusia mukmin yang taqwa, berpengetahuan luas dan dalam, berbudi pekerti yang tinggi, cerdas dan tangkas dalam berjuang, serta menuntut kebahagiaan dunia akhirat."33

\section{Tipologi Pendidikan}

Sejarah membuktikan bahwa Al-Washliyah memberikan perhatian cukup besar terhadap 3 (tiga) bidang, yakni pendidikan, dakwah dan sosial. Dalam dunia pendidikan, AlWashliyah telah memberikan kontribusi nyata. Secara teoretis, organisasi ini telah memiliki konsep pendidikan tersendiri,

${ }^{31}$ Majelis Pendidikan, Pengajaran dan Kebudayaan PB Al-Washliyah, Pola Pembangunan Al-jam'iyatul Washliyah dalam Bidang Pendidikan, Pengajaran dan Kebudayaan (Makalah tidak diterbitkan).

32Pengurus Besar Al-Jam'iyatul Washliyah, "Sistem Pendidikan AlWashliyah," dalam Pedoman Penyelenggaraan Pendidikan Al-Jam'iyatul Washliyah, ed. Pengurus Besar Al-Washliyah (Jakarta: PB Al-Washliyah, 2000).

${ }^{33}$ Nukman Sulaiman, Pedoman Guru (Medan: Pustaka UNIVA, 1967), 11. 
meskipun konsep tersebut memiliki sejumlah persamaan dengan konsep pendidikan pada umumnya. Al-Washliyah telah mengembangkan pendidikan informal, formal, dan non-formal. Dalam sidang Muktamar Al-Washliyah XIV tahun 1978 di Medan, Sumatera Utara, disebutkan bahwa rencana pembangunan Al-Washliyah dalam bidang pendidikan mencakup tiga lapangan pendidikan, yakni pendidikan rumah tangga, pendidikan madrasah atau perguruan, dan pendidikan masyarakat. ${ }^{34}$ Organisasi ini memandang bahwa ketiga lapangan pendidikan ini sangat penting, sehingga ketiganya harus mendapat perhatian.

Dalam rangka mencapai tujuan Al-Washliyah dan tujuan pendidikannya, menurut Sistem Pendidikan Al-Washliyah tahun 2003, Al-Washliyah memberikan perhatian kepada dua jalur pendidikan, yakni pendidikan formal dan pendidikan nonformal. Dalam sistem pendidikan ini, Al-Washliyah tidak memasukkan pendidikan informal menjadi bagian dari sistem pendidikannya, berbeda dengan rumusan MPPK Al-Washliyah tahun 1973. Tetapi, revisi sistem pendidikan Al-Washliyah kembali memuat pendidikan informal tersebut. ${ }^{35}$ Dalam Pedoman Penyelenggaraan Pendidikan Al-Washliyah, disebutkan bahwa jenjang pendidikan Al-Washliyah terdiri atas empat jenjang: pendidikan Prasekolah, pendidikan dasar, pendidikan menengah, dan pendidikan tinggi. Berdasarkan keempat jenjang itu, AlWashliyah mengembangkan beberapa jenis pendidikannya, yaitu: 36

1. Pendidikan Prasekolah, yaitu Raudhatul Athfal, Taman Kanak-Kanak Al-Washliyah dan Pendidikan Anak Usia Dini;

2. Pendidikan Dasar, terdiri atas:

a. Sekolah Dasar Al-Washliyah/Madrasah Ibtidaiyah AlWashliyah/Ibtidaiyah Salafiyah Al-Washliyah;

${ }^{34} \mathrm{MPK}$ PB Al-Washliyah, 'Pola..., 1.

35Pengurus Besar Al-Washliyah, Pedoman Penyelenggaraan Pendidikan Tinggi Al Jam iyatul Washliyah (Jakarta: PB Al-Washliyah, 2011), 11.

36PB Al-Washliyah, "Sistem...," 8-9. 


\section{b. Sekolah Lanjutan Tingkat Pertama Al- Washliyah/Madrasah Tsanawiyah Al- Washliyah/Tsanawiyah Salafiyah Al-Washliyah.}

3. Pendidikan Menengah, terdiri atas:
a. Sekolah Menengah Umum/Madrasah Aliyah/Qismul 'Aliy y Al-Washliyah/Muallimin Al-Washliyah;
b. Sekolah Menengah Kejuruan (SMK) Al-Washliyah;

4. Pendidikan Tinggi, terdiri atas Universitas, Institut, Sekolah Tinggi, dan Politeknik/Akademi. ${ }^{37}$

Tujuan lembaga-lembaga pendidikan tersebut tunduk kepada tujuan pendidikan Al-Washliyah. Adapun tujuan pendidikan AlWashliyah terbaru adalah 1) menghasilkan manusia mukmin yang bertakwa, berilmu pengetahuan luas dan mendalam, berakhlakul karimah, sukses di dunia dan selamat di akhirat; 2) mengembangkan dan menyebarkan ilmu pengetahuan, teknologi, dan/atau kesenian serta mengupayakan penggunaannya untuk meningkatkan taraf hidup masyarakat untuk mencapai kebahagiaan dunia dan akhirat; 3) menghasilkan sumber daya manusia yang berkualitas kader untuk melanjutkan perjuangan dan amaliyah Al-Washliyah; 4) menghasilkan ulama uswatun hasanah yang menjadi panutan umat. ${ }^{38}$

Dalam rangka menghasilkan ulama, Al-Washliyah memiliki madrasah yang khusus mendidik calon ulama Al-Washliyah masa depan. Madrasah Al Qismul 'Aliy y (MAQ) Al-Washliyah dan Madrasah Aliyah Muallimin (MAM) didirikan oleh Al-Washliyah dalam rangka menghasilkan ulama-ulama masa depan. ${ }^{39}$

Dapat disimpulkan bahwa Al-Washliyah mengembangkan dua corak pendidikan: pendidikan umum dan pendidikan agama. Meskipun dibagi menjadi dua corak, namun organisasi ini tidak mengenal dikhotomi antara pendidikan agama dan pendidikan umum secara radikal. Sebab, kedua corak lembaga pendidikan Al-Washliyah ini sama-sama hendak menanamkan nilai-nilai keagamaan dan keilmuan secara integratif sesuai dengan tujuan umum pendidikan Al-Washliyah.

${ }^{37} \mathrm{~PB}$ Al-Washliyah, Pedoman Penyelenggaraan Pendidikan Tinggi Al Jam‘iyatul Washliyah, 12.

${ }^{38}$ Ibid., 11.

${ }^{39} \mathrm{~PB}$ Al-Washliyah, "Sistem..., 34. 


\section{Eksistensi Lembaga Pendidikan}

Kendati menjadi organisasi yang disegani, Al-Washliyah lebih berpengaruh di kawasan pantai timur Sumatera Utara, karena mayoritas penduduk pantai timur menganut agama Islam. Kontribusi Al-Washliyah dalam aspek pendidikan tidak bisa diabaikan, karena sejarah telah mencatat dengan akurat peran AlWashliyah dalam mencerdaskan anak bangsa melalui lembagalembaga pendidikannya. Secara nasional, menurut keterangan MPK PB Al-Washliyah tahun 2009, bahwa Al-Washliyah memiliki sekitar 700 lebih lembaga pendidikan, ${ }^{40}$ mulai dari jenjang TK hingga Madrasah Aliyah, dan mempunyai 12 perguruan tinggi. ${ }^{41}$ Untuk Sumatera Utara, menurut laporan Majelis Pendidikan dan Kebudayaan Al-Jam'iyatul Washliyah Sumatera Utara tahun 1995 tentang Nama dan Alamat Sekolah/Madrasah Al-Jam'iyatul Washliyah Sumatera Utara, disebutkan bahwa jumlah Sekolah/Madrasah Al-Washliyah Sumatera Utara adalah 615 unit, yang terdiri atas 461 unit sekolah umum dan 461 unit sekolah agama. ${ }^{42}$

Dalam Laporan Umum Pimpinan Wilayah Al-Jam'iyatul Washliyah Sumatera Utara dalam Musyawarah Wilayah X AlJam'iyatul Washliyah Sumatera Utara tanggal 25-28 Juli 2003 menyebutkan bahwa Majelis Pendidikan dan Kebudayaan (MPK) Al-Washliyah Sumatera Utara memiliki 148 sekolah umum dalam berbagai jenis dan 461 sekolah agama dalam berbagai jenis. Jadi, total sekolah dan madrasah Al-Washliyah adalah 609 unit. Secara kuantitas, jenis-jenis sekolah umum AlWashliyah tersebut adalah 9 unit Taman Kanak-Kanak TK), 96 unit Sekolah Dasar (SD), 39 unit Sekolah Lanjutan Pertama (SLTP), 5 unit Sekolah Menengah Umum (SMU) dan 9 unit Sekolah Menengah Kejururuan (SMK). Sedangkan jenis-jenis sekolah agama Al-Washliyah tersebut adalah 3 unit Taman

${ }^{40}$ Lihat "Hak Paten Lambang dan Nama Al-Washliyah Segera di Sosialisasikan," bttp://www.Al-Washliyah.com, diakses tanggal 14 Juli 2009.

${ }^{41}$ Lihat "Al-Washliyah Siap Kritis Terhadap Pemerintah," dalam http:/ / www.republika.com, diakses tanggal 5 April 2010.

${ }^{42}$ Lihat Majelis Pendidikan dan Kebudayaan Al-Jam'iyatul Washliyah Sumatera Utara, Nama dan Alamat Sekolah/Madrasah Al-Jam'iyatul Washliyah Propinsi Sumatera Utara (Medan: MPK Al-Washliyah, 1995), ii. 
Kanak-Kanak (TK) Agama, 283 Madrasah Ibtidaiyah dan Madrasah Tsanawiyah (MI/MTs) Al-Washliyah, 112 unit Madrasah Aliyah (MAS) Al-Washliyah, 58 unit Madrasah Al Qismul 'Aliy (MAQ) dan 5 unit Madrasah Aliyah Muallimin (MAM). ${ }^{43}$ Patut diketahui bahwa sejak tahun 2003, Pedoman Penyelenggaraan Pendidikan Al-Jam'iyatul Washliyah tahun 2000 telah disosialisasikan dan direalisasikan secara baik oleh pimpinan $\mathrm{Al}$ Washliyah di seluruh Indonesia.

Namun menurut data Majelis Pendidikan dan Kebudayaan Al-Washliyah Sumatera Utara tahun 2011, sebagaimana dikatakan Dedi Iskandar, saat ini terdapat 627 unit sekolah/madrasah Al-Washliyah dari mulai TK sampai SLTA. ${ }^{44}$ Dengan demikian, ada penambahan jumlah sekolah dan madrasah Al-Washliyah di Sumatera Utara antara tahun 1995 sampai tahun 2011.

Sementara itu, perguruan tinggi Al-Washliyah di Sumatera Utara pada tahun 2003 berjumlah 4 unit. Perguruan Tinggi AlWashliyah di kota Medan berjumlah 2 unit, yaitu Universitas AlWashliyah (UNIVA) Medan dan Universitas Muslim Nusantara (UMN) Al-Washliyah, sedangkan di Sibolga berjumlah 1 unit yaitu Sekolah Tinggi Ilmu Ekonomi (STIE) Al-Washliyah, dan di Rantauprapat berjumlah 1 unit yaitu Sekolah Tinggi Agama Islam (STAI) Al-Washliyah. ${ }^{45}$

Diketahui bahwa Al-Washliyah telah memiliki beberapa perguruan tinggi di sejumlah provinsi di Indonesia antara lain Sekolah Tinggi dan Ilmu Keguruan (STKIP) Al-Washliyah Banda Aceh, Sekolah Tinggi Ilmu Sosial Politik (STISIP) AlWashliyah Banda Aceh, Sekolah Tinggi Agama Islam (STAI) AlWashliyah Banda Aceh, ${ }^{46}$ Universitas Al-Washliyah (UNIVA)

43Pimpinan Wilayah Al-Jam'iyatul Washliyah, Laporan Umum Pimpinan WIlayah Al-Jam'iyatul Washliyah Sumatera Utara: Musyawarah Wilayah X AlJam'iyatul Washliyah Sumatera Utara (Medan: PW Al-Washliyah Sumatera Utara, 2003), 8-10.

${ }^{44}$ Dedy Iskandar Batubara, "Merestrukturisasi Bangunan Al-Washliyah," Waspada, 13 Januari 2011.

${ }^{45}$ Ibid., 10.

46Ja'far, "Geliat Al-Washliyah di Negeri Syariat," dalam Al-Jam'iyatul Washliyah: Potret Histori, Edukasi dan Filosofi, ed. Ja'far (Medan: Perdana Publishing dan Center for Al-Washliyah Studies, 2011), 63. 
Medan, Universitas Muslim Nusantara (UMN) Al-Washliyah, Sekolah Tinggi Ilmu Ekonomi (STIE) Al-Washliyah Sibolga, Sekolah Tinggi Ilmu Tarbiyah (STIT) Al-Washliyah Binjai, Universitas Al-Washliyah (UNIVA) Labuhanbatu, ${ }^{47}$ dan Sekolah Tinggi Agama Islam (STAI) Al-Washliyah Barabai, Kalimantan Selatan. ${ }^{48}$ Sampai tahun 2010, Al-Washliyah tidak memiliki perguruan tinggi yang berbentuk institut, Politeknik dan Akademi, meskipun ketiga jenis perguruan tinggi ini dijelaskan dalam sistem pendidikan Al-Washliyah.

Memang ada perubahan kuantitas dan kualitas perguruan tinggi Al-Washliyah di Sumatera Utara selama sepuluh tahun terakhir. Pada tahun 1997, Al-Washliyah hanya memiliki 5 (lima) perguruan tinggi, yaitu UNIVA Medan, UMN Al-Washliyah, Fakultas Tarbiyah Al-Washliyah Barabai, STAI Al-Washliyah Labuhanbatu, dan STIE Al-Washliyah Sibolga. Periode berikutnya, STAI Al-Washliyah Labuhanbatu berubah status dari sekolah tinggi menjadi universitas, yaitu Universitas AlWashliyah (UNIVA) Labuhanbatu, sedangkan Fakultas Tarbiyah Al-Washliyah Barabai menjadi Sekolah Tinggi Agama Islam (STAI) Al-Washliyah Barabai. Selain itu, Pimpinan Daerah AlWashliyah Banda Aceh mendirikan 3 (tiga) sekolah tinggi yaitu STKIP Al-Washliyah, STISIP Al-Washliyah dan STAI AlWashliyah Banda Aceh, sedangkan Pimpinan Daerah AlWashliyah Binjai mendirikan STIT Al-Washliyah Binjai. Tampaknya perguruan tinggi Al-Washliyah akan terus bertambah secara kuantitas, karena Pimpinan Daerah AlWashliyah Kota Banda Aceh sedang mendirikan Sekolah Tinggi Ilmu Ekonomi Islam (STIEI) Al-Washliyah di Aceh.

Meskipun demikian, secara kuantitas dan barangkali kualitas, Al-Washliyah masih kalah dengan Muhammadiyah dan Nahdlatul Ulama (NU). Jumlah total lembaga pendidikan Muhammadiyah adalah 10.314 unit dengan rincian TK/TPQ

${ }^{47} \mathrm{Al}$ Rasyidin, "Dinamika Historis Al-Jam'iyatul Washliyah di Sumatera Utara," dalam Al-Jam'iyatul Washliyah: Potret Histori, Edukasi dan Filosofi, ed. Ja'far (Medan: Perdana Publishing dan Center for Al-Washliyah Studies, 2011), 55-8.

${ }^{48}$ Hasbi Jasin, Sekilas Catatan Muktamar Penuh Kasib Sayang Menghasilkan Demokrasi Yang Utuh (Jakarta: PB Al-Washliyah, 1997), 39. 
Muhammadiyah sebanyak 4.623 unit, SD/MI Muhammadiyah adalah sebanyak 2.604 unit, SMP/MTs Muhammadiyah sebanyak 1.772 unit, SMA/MA/SMK Muhammadiyah sebanyak 1.143 unit, jumlah Perguruan Tinggi Muhammadiyah sebanyak 172 unit. ${ }^{49}$ Sedangkan total jumlah lembaga-lembaga pendidikan milik NU adalah 12094 unit dengan rincian Madrasah Ibtidaiyah (MI) sebanyak 7452 unit, Madrasah Tsanawiyah (MTs) sebanyak 2991 unit; Madrasah Aliyah (MA) sebanyak 1002 unit, Perguruan Tinggi (PT) sebanyak 81 unit, Sekolah Dasar (SD) sebanyak 80 unit, Sekolah Menengah Pertama (SMP) sebanyak 278 unit; Sekolah Menengah Pertama (SMA) sebanyak 71 unit, dan Sekolah Menengah Kejuruan (SMK) sebanyak 137 unit. $^{50}$

\section{Catatan Akhir}

Dapat disimpulkan bahwa organisasi Al-Washliyah berasal dari para ulama dan telah melahirkan banyak ulama. Organisasi ini telah memainkan peran sebagai perisai dan benteng bagi mazhab Sunni di Sumatera Utara. Dalam usaha menunaikan ajaran Islam demi meraih kebahagiaan dunia dan akhirat, AlWashliyah komitmen terhadap mazhab fikih Syafi'iyah dan teologi Asy'ariyah, kendati belakangan organisasi ini tidak menutup diri terhadap mazhab fikih Malikiyah, Hanafiyah dan Hanbaliyah.

Dalam usaha mencapai tujuan organisasi, sejak awal berdiri Al-Washliyah mendirikan banyak lembaga pendidikan. Tidak sekadar mendirikan, organisasi ini memiliki majelis yang mengurusi masalah pendidikan yang bertugas merumuskan dan merevisi sistem pendidikan Al-Washliyah. Dari aspek sebaran daerah, lembaga-lembaga Al-Washliyah berada di sejumlah daerah seperti Medan, Binjai, Tebing Tinggi, Sibolga, Tanjung Balai, Pematang Siantar, Langkat, Karo, Deli Serdang, Asahan, Labuhanbatu, Simalungun, Tapanuli Selatan, Tapanuli Tengah dan Nias. Data tahun 2003 menunjukkan bahwa Al-Washliyah memiliki 148 unit sekolah umum dan 461 unit sekolah agama 2011.

${ }^{49}$ http://mdc.umm.ac.id/institusi/tk, diakses tanggal 23 Desember

50http://www.maarif-nu.or.id/dbmain.php, diakses tanggal 23 Desember 2011. 
dari berbagai jenis. Kuantitas sekolah dan madrasah setiap daerah cenderung berbeda antara satu daerah dengan daerah lain, namun jumlah sekolah dan madrasah Al-Washliyah yang terbesar berada di daerah Medan, Deli Serdang, Asahan dan Labuhanbatu. Sekolah dan madrasah Al-Washliyah diperkuat oleh 5 (lima) perguruan tingginya, yang terdiri atas 3 universitas dan 2 sekolah tinggi, yaitu UNIVA Medan, UMN Al-Washliyah, UNIVA Labuhanbatu, STIT Binjai dan STIE Al-Washliyah Sibolga. Wa al-Lāh a lam bi al-sawāh.

\section{Daftar Pustaka}

"Al-Washliyah Siap Kritis terhadap Pemerintah," dalam http:/ / www.republika.com, diakses tanggal 5 April 2010.

"Hak Paten Lambang dan Nama Al-Washliyah Segera di Sosialisasikan," http://www.Al-Washliyah.com, diakses tanggal 14 Juli 2009.

Al Rasyidin. 2011. "Dinamika Historis Al-Jam'iyatul Washliyah di Sumatera Utara," dalam Al-jam'iyatul Washliyah: Potret Histori, Edukasi dan Filosofi, ed. Ja'far. Medan: Perdana Publishing dan Center for Al-Washliyah Studies.

Asari, Hasan. 2002. Modernisasi Islam: Tokoh, Gagasan dan Gerakan. Bandung: Citapustaka Media.

Batubara, Dedy Iskandar. "Merestrukturisasi Bangunan AlWashliyah," Waspada, 13 Januari 2011.

Batubara, Ismed dan Ja'far (ed.). 2010. Bunga Rampai Al-Jam'iyatul Washliyah. Banda Aceh: Al-Washliyah University Press.

http://mdc.umm.ac.id/institusi/tk, diakses tanggal 23 Desember 2011.

http://www.maarif-nu.or.id/dbmain.php, diakses tanggal 23 Desember 2011.

Ja'far. 2007. "Maktab Islamiyah Tapanuli: Sebuah Cermin Berharga Bagi HIMMAH," dalam Potret HIMMAH: Menyibake Sejarah, Gerakan dan Identitas, ed. Ja'far dan Ahmad Mushlih. Banda Aceh: PeNA.

2011. "Geliat Al-Washliyah di Negeri Syariat," dalam Al-jam'iyatul Washliyah: Potret Histori, Edukasi dan 
Filosofi, ed. Ja'far. Medan: Perdana Publishing dan Center for Al-Washliyah Studies.

\section{Biografi Intelektual Ulama-ulama Al-}

Washliyah. Medan: Centre for Al-Washliyah Studies.

Jasin, Hasbi. 1997. Sekilas Catatan Muktamar Penuh Kasib Sayang Menghasilkan Demokrasi Yang Utuh. Jakarta: PB Al-Washliyah. Lubis, Muhammad Arsyad Thalib. 1982. Fatwa: Beberapa Masalah. Medan: Firma Islamiyah. . 1982. Ilmu Fikih. Medan: Firma Islamiyah.

Lubis, Muhammad Ridwan Ibrahim. 1994. Kepribadian Anggota \& Pengurus Al-Washliyah. Jakarta: PP HIMMAH.

Majelis Pendidikan dan Kebudayaan Al-Jam'iyatul Washliyah Sumatera Utara. 1995. Nama dan Alamat Sekolah/Madrasah Al-Jam'iyatul Washliyah Propinsi Sumatera Utara (Medan: MPK Al-Washliyah.

Majelis Pendidikan, Pengajaran dan Kebudayaan PB AlJam'iyatul Washliyah. tt. Pola Pembangunan Al-Jam'iyatul Washliyah dalam Bidang Pendidikan, Pengajaran dan Kebudayaan (Makalah tidak diterbitkan).

Majelis Ulama Indonesia Sumatera Utara. tt. Ulama-ulama Terkemuka di Sumatera Utara. Medan: MUI Sumatera Utara.

Noer, Deliar. 1980. Gerakan Modern Islam di Indonesia. Jakarta: LP3ES.

Pengurus Besar Al-Jam'iyatul Washliyah, 2010. Anggaran Dasar dan Anggaran Rumah Tangga Al-Jam'iyatul Washliyah. Jakarta: PB Al-Washliyah.

. 1955. "Anggaran Dasar dan Anggaran Rumah Tangga Al Djamiatul Washlijah," dalam Al-Jam'iyatul Washlijah 1/4 Abad, ed. Nukman Sulaiman. Medan: PB AlWashliyah.

\section{Washliyah.} . 1977. Al-Jam'iyatul Washliyah. Medan: PB Al1985. “Anggaran Dasar Al-Jam'iyatul Washliyah," dalam Buah Hati Umat-Islam dan Keputusan Muktamar Al-Washliyah ke-XV Pekan Baru-Riau, ed. Bahrum Jamil. Medan: Wajah Islam.

1985. "Keputusan-Keputusan Muktamar AlJam’iyatul Washliyah Tanggal 24-27 September 1978/22-24 
Syawal 1398 H di Pekan Baru-Riau," dalam, Buah Hati UmatIslam dan Keputusan Muktamar Al-Washliyah ke-XV Pekan Baru-Riau, ed. Bahrum Jamil. Medan: Wajah Islam. . 2000. "Sistem Pendidikan Al-Washliyah," dalam Pedoman Penyelenggaraan Pendidikan Al-Jam'iyatul Washliyah, ed. Pengurus Besar Al-Washliyah. Jakarta: PB Al-Washliyah. 2003. Anggaran Dasar dan Anggaran Rumah Tangga Al-Jam'iyatul Washliyah Periode 2003-2008. Jakarta: PB Al-Washliyah.

2010. Anggaran Dasar dan Anggaran Rumah Tangga Al-Jam'iyatul Washliyah Periode 2010-2015. Jakarta: Pengurus Besar Al-Jam'iyatul Washliyah.

. 2011. Pedoman Penyelenggaraan Pendidikan Tinggi Al Jam'iyatul Washliyah. Jakarta: PB Al-Washliyah.

Pengurus Pusat Ikatan Putera-Puteri Al-Washliyah. 2003. Anggaran Dasar dan Anggaran Rumah Tangga Ikatan PuteraPuteri Al-Washliyah. Jakarta: PP IPA.

Pimpinan Daerah Al-Jam'iyatul Washliyah Kota Medan. 2003. Laporan Pertanggungjawaban Pimpinan Daerah Al-Washliyah Kota Medan periode 1998-2003. Medan: PD Al-Washliyah Kota Medan.

Pimpinan Wilayah Al-Jam'iyatul Washliyah. 2003. Laporan Umum Pimpinan WIlayah Al-Jam'iyatul Washliyah Sumatera Utara: Musyawarah Wilayah X Al-Jam'iyatul Washliyah Sumatera Utara. Medan: PW Al-Washliyah Sumatera Utara..

Sjamsuddin, Udin. 1955. Chutbah Pengurus Besar Memperingati

Ulang Tahun Al Djamijatul Washlijah. Medan: PB Al Washlijah.

Steenbrink, Karel A. 1986. Pesantren, Madrasah, Sekolah: Pendidikan Islam dalam Kurun Modern. Jakarta: LP3ES. . 1988. "Kata Pengantar," dalam Chalidjah Hasanuddin, Al-Jam'iyatul Washliyah 1930-1945: Api Dalam Sekam di Sumatera Timur. Bandung: Pustaka.

Sulaiman, Nukman (ed.). 1956. Al Jam'ijatul Washlijab 1/4 Abad. Medan: PB Al Washlijah. 1967. Pedoman Guru. Medan: Pustaka UNIVA. . 1972. 'Aqidah Islamiyah (Pokok-pokok Kepercayaan dalam Islam). Medan: Pustaka UNIVA. 
1986. Bermu'tamarlah dengan Baik: Anjuran Dewan

Fatwa, Penasibat, dan Pertimbangan p.b. al- j. washliyah (Muktamar Al-Washliyah XVI di Jakarta) 20-24 Pebruari 1986. Medan: UNIVA.

Tanjung, Muaz. 2004. "Pendidikan Islam di Medan Pada Awal Abad ke-20: Studi Historis tentang Maktab Islamiyah Tapanuli (1918-1942)", Tesis. Medan: PPS IAIN-SU.

Wahid, Ramli Abdul. 2009. "Al-Jam'iyatul Washliyah: Studi Tentang Madzhab Akidah dan Fikih," dalam Peran Moderasi Al-Washliyah: Merajut Kebersamaan Zaman Berzaman, ed. Saiful Akhyar Lubis. Medan: UNIVA Press.

Wahid, Ramli Abdul. 2012. Fikih Ramadan. Medan: Perdana Publishing.

Yunus, Mahmud. 1993. Sejarah Pendidikan Islam di Indonesia. Jakarta: Hidakarya Agung. 